\title{
STUDIES ON THE INFLUENCE OF VITAMIN A AND VITAMIN C ON CERTAIN IMMUNOLOGICAL REACTIONS IN MAN ${ }^{1,2}$
}

\author{
By A. E. FELLER, LESLIE B. ROBERTS, ELAINE P. RALLI, \\ AND THOMAS FRANCIS, JR. \\ (From the Department of Bacteriology and the Department of Medicine, New York University, \\ College of Medicine, and from the Third (New York University) Medical \\ Division, Bellevue Hospital, New York City)
}

(Received for publication August 18, 1941)

There has been considerable difference of opinion concerning the influence of the vitamins upon resistance to infection (1). Many of the published reports, based to a great extent upon studies in experimental animals, have tended to suggest that vitamin $\mathrm{A}$ and vitamin $\mathrm{C}$ are especially important in maintaining resistance (2). The rôle of these vitamins in the resistance of human subjects to infection has not been satisfactorily established.

The present study was undertaken to reinvestigate the influence of vitamin $\mathrm{A}$ and vitamin $\mathrm{C}$ upon a series of immunological reactions in patients receiving diets adequate in all other factors except the specific vitamin, the influence of which was to be studied. The following immunological phenomena were studied: (1) the capacity of the patient's nasal secretions to inactivate influenza virus $(3)$; (2) the titer in the patient's blood serum of neutralizing antibodies for influenza virus; (3) the activity of lysozyme in the nasal secretions; (4) the titer of complement in blood serum; and (5) the phagocytic activity for pneumococci of polymorphonuclear neutrophilic leukocytes in whole, heparinized blood.

\section{METHODS}

\section{Selection and care of patients}

The five subjects were patients in the wards of the Third (New York University) Medical Division of Bellevue Hospital. Three of them had been admitted to the hospital for some minor complaint; one patient had cirrhosis of the liver and the other had ankylosing spondylitis. All patients were under the observation of a special nurse.

\section{Dietary measures}

Each patient received a diet which was deficient either in vitamin $A$ or vitamin $C$ but which was adequate in

1 This research was aided by a grant from the Josiah Macy, Jr. Foundation.

2 The cod liver oil concentrate used in this study was supplied by the Lederle Laboratories, Inc. calories and all other foodstuffs. In addition, each patient received a daily supplement of 10 to $20 \mathrm{mgm}$. thiamine chloride, 50 to $100 \mathrm{mgm}$. nicotinic acid, 1 to $2 \mathrm{mgm}$. riboflavin and 15 to 30 grams of dried brewers' yeast. Furthermore, patients who were on the diet deficient in vitamin A received 100 to $200 \mathrm{mgm}$. of ascorbic acid daily; patients on the diet deficient in vitmin $C$ received 100,000 to 300,000 U.S.P. units of vitamin $A$ in the form of a cod liver oil concentrate daily.

The diets were prepared by the University dietitian. The diet deficient in vitamin A contained not more than 300 U.S.P. units of vitamin A per day (Table I). The

TABLE I

Breakfast

Vitamin $A$ deficient diet

Fruit

Cereal

Skimmed milk, one pint

Bread, three slices

Coffee

Lunch

Lean beef or fish

Potato, rice or spaghetti

Skimmed milk, one pint

Bread, three slices

Plain pudding, Jello, fruit or ice cream

Supper

Lean beef or cottage cheese

Rice, potato or spaghetti

Skimmed milk, one pint

Bread, three slices

Dessert, same as for lunch

Butter, eggs and vegetables were excluded from the diet and Mazola oil was used to cook the meat and fish.

The only significant source of vitamin $A$ in the $\operatorname{diet}$ was the milk which was skimmed and contained not more than 20 U.S.P. units of vitamin A per $100 \mathrm{cc}$.

diet deficient in vitamin $C$ contained about $5 \mathrm{mgm}$. of vitamin $C$ per day (Table II).

\section{Vitamin determinations}

Weekly or bi-weekly determinations of the amount of vitamin $A$, carotene and vitamin $C$ in the blood plasma of each patient were made. The amount of vitamin $C$ in the white blood cell-platelet layer was determined at intervals. All of the determinations, except where specifically indicated otherwise, were made on blood ob- 
TABLE II

Vitamin C deficient diet

Breakfast

Cereal, with sugar

Skimmed milk, one pint

Egg, one only

Bread, three slices, with butter

Lunch

Lean beef or fish

Rice, spaghetti or noodles

Skimmed milk, one pint

Bread, three slices, with butter

Plain pudding, custard, Jello or ice cream

Supper

Cheese, egg or lean beef

Rice, noodles or spaghetti

Skimmed milk, one pint

Bread, three slices, with butter

Dessert, same as for lunch

Fruit and vegetables were excluded from the diet.

tained from the patient 24 hours after the last administration of vitamin A or vitamin C.

The concentration of vitamin $A$ in the plasma was determined in the photoelectric colorimeter by the method reported by Kimble (4). The amount of carotene in the plasma was determined in the photoelectric colorimeter by the method described by Stueck et al. (5).

The content of vitamin $C$ in the plasma was determined in the photoelectric colorimeter by the method of Mindlin and Butler (6), using methylene blue as the indicator in place of 2, 6 dichlorophenol indophenol. The concentration of vitamin $\mathrm{C}$ in the white blood cell-platelet layer was measured by the method of Butler and Cushman (7).

It has been reported by others (4) and substantiated by Ralli et al. (8) that in normal adults the level of vitamin $\mathrm{A}$ in the plasma, as determined in the photoelectric colorimeter, varies from 88 to 220 U.S.P. units per 100 cc. and the amount of carotene in the plasma varies from 0.080 to $0.280 \mathrm{mgm}$. per cent.

In normal adults the amount of vitamin $C$ in the plasma is above $0.4 \mathrm{mgm}$. per cent. The concentration of the vitamin in the white blood cell-platelet layer is about 25 mgm. per 100 grams (9). The best test at present available for detecting a profound depletion of the stores of vitamin $C$ in the tissues of humans, prior to the appearance of the symptoms of scurvy, is the determination of the amount of vitamin $C$ in the white blood cell-platelet layer. A decrease in the amount of vitamin $C$ in the plasma precedes any decrease in the amount of ascorbic acid in the white blood cell-platelet layer. When vita$\min C$ is absent from the plasma the subject can be considered to be in a state of vitamin $C$ subnutrition. When the vitamin is absent from the white blood cell-platelet layer the subject is approaching the clinical state of scurvy.

\section{Immunological tests}

Materials for the various immunological tests were obtained each week or, in certain instances, every second week.

\section{Determination of the capacity of the nasal secretions to inactivate influenza virus}

Nasal secretions were obtained by inserting pledgets of dry cotton into the middle meatus of the nose. After the cotton had become well soaked, the clear fluid was expressed. This material was stored at $4^{\circ} \mathrm{C}$. and each specimen was subjected to the same period of storage before testing. The virus was obtained from infected mouse lung which had been ground with alundum and, after light centrifugation, diluted 1:500 with 10 per cent normal horse serum in physiological sodium chloride solution. Serial, two-fold dilutions of the nasal secretions in physiological sodium chloride solution were made and to $0.15 \mathrm{cc}$. of each dilution an equal volume of a suspension of the PR8 (10) strain of type A epidemic influenza virus, containing 6,000 lethal doses, was added. The nasal secretions-virus mixtures were incubated at $37^{\circ} \mathrm{C}$. for 30 minutes and then $0.05 \mathrm{cc}$. of each mixture (containing 1,000 lethal doses of virus) was given intranasally to each of three C.F.W. Swiss mice lightly anesthetized with ether. The mice were observed for 10 days, all deaths were recorded daily, and all survivors were sacrificed and autopsied. The end point of the titration was that final dilution of nasal secretions which protected 50 per cent of the mice from death in 10 days (11). Since these tests were made at weekly intervals, the potency of the virus was determined each week to permit a standardization of the results.

\section{Determination of influenza virus neutralizing antibody in blood serum}

These tests were performed in exactly the same manner as those with nasal secretions except that double volumes of diluted serum and virus suspension were placed in the mixture.

A single, standard serum was included in most tests for influenza virus inactivating substance in nasal secretions and influenza virus neutralizing antibody in blood serum. The uniformity of titer as shown in Figure 1 indicates that the results obtained in different tests are strictly comparable since the range of variability fell within one dilution.

\section{Determination of lysozyme in nasal secretions}

Serial, two-fold dilutions of nasal secretions were made in physiological sodium chloride solution and $0.5 \mathrm{cc}$. of each dilution was added to $0.5 \mathrm{cc}$. of an 18-hour culture of the susceptible microorganism in pneumococcus broth. The mixtures were incubated for one hour at $37^{\circ} \mathrm{C}$. The end point was taken as the highest initial dilution of nasal secretions which produced complete lysis of the bacteria.

To ensure uniformity of the bacterial suspensions, tubes containing $8 \mathrm{cc}$. of broth were seeded with $0.2 \mathrm{cc}$. of the culture which had been used the previous week and subsequently stored at $4^{\circ} \mathrm{C}$. The microorganism employed was a gram positive coccus which produced alpha hemolysis, was not soluble in bile and did not ferment inulin. 


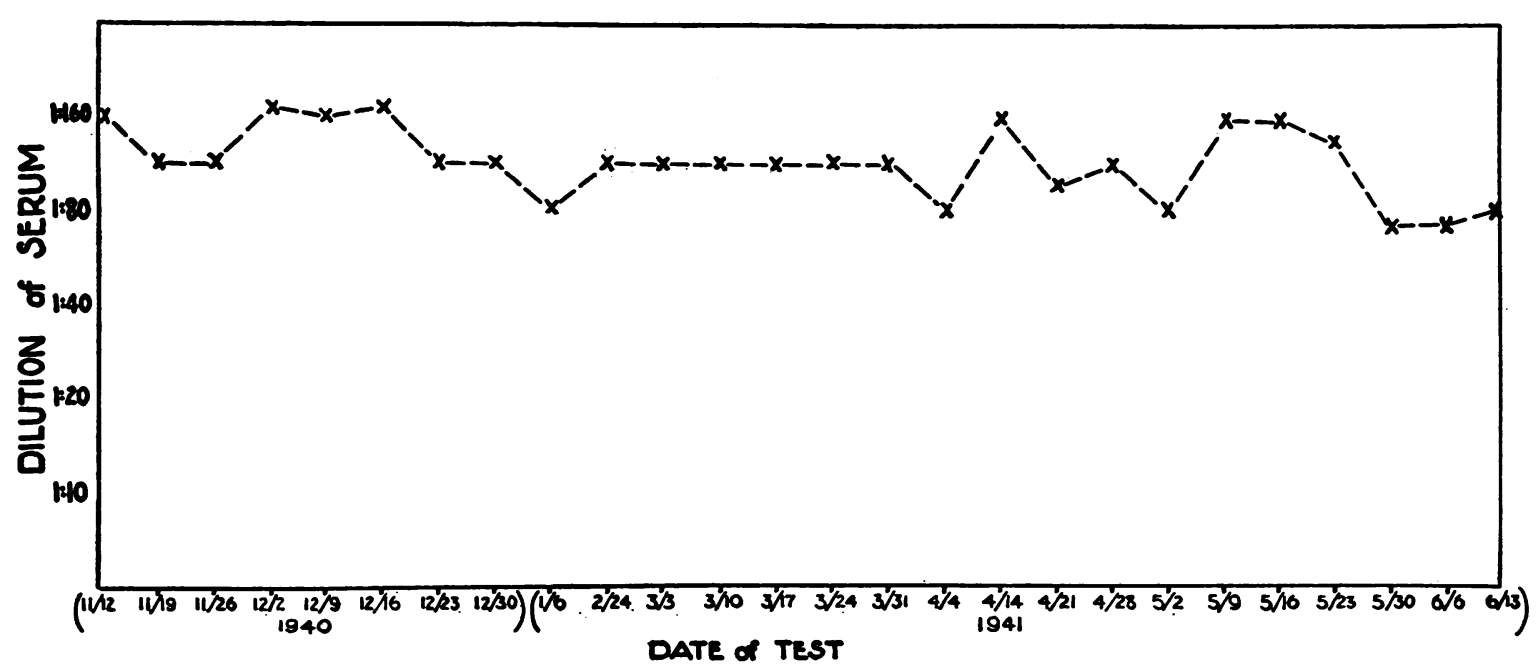

Fig. 1. Titers of Influenza Virus Neutralizing Antibody as Determined by Repeated Tests of a Single, Standard Serum

The substance which was being measured in these tests had the properties of lysozyme (12) since the nasal secretions could be heated at $100^{\circ} \mathrm{C}$. for 30 minutes at $\mathrm{pH} 4.5$ and when restored to $\mathrm{pH} 7$ would still cause lysis of the test organism, although the potency was reduced by 50 per cent. Of note was the observation that this treatment completely destroyed the ability of the nasal secretions to inactivate influenza virus.

\section{Determination of complement in blood serum}

Blood was drawn into partial vacuum venules 3 and stored at $4^{\circ} \mathrm{C}$. for 30 hours, at which time the serum was removed and titrated. The serum was diluted $1: 10$, $1: 20,1: 30,1: 40,1: 60,1: 80,1: 100,1: 120$ and $1: 160$ in physiological sodium chloride solution. Five-tenths cc. of sensitized sheep red blood cells was added to $0.5 \mathrm{cc}$. of each dilution of serum and the mixtures incubated for one hour at $37^{\circ} \mathrm{C}$. Two end points were read: first, the highest initial dilution of serum producing complete hemolysis and, second, the highest initial dilution of serum producing the least detectable trace of hemolysis, as judged by inspecting the supernate following centrifugation. Control tests consisting of $0.5 \mathrm{cc}$. of each dilution of the patient's serum, $0.25 \mathrm{cc}$. of unsensitized sheep red blood cells and $0.25 \mathrm{cc}$. of physiological sodium chloride solution were always included.

The same lot of amboceptor served as a source of hemolysin for all tests and $0.25 \mathrm{cc}$. was employed to sensitize $0.25 \mathrm{cc}$. of the sheep red blood cells. The latter were washed with physiological sodium chloride solution before use.

\section{Determination of the phagocytic index}

Approximately $0.75 \mathrm{cc}$. of the patient's blood was drawn into $0.1 \mathrm{cc}$. of 0.05 per cent heparin in physiological sodium chloride solution and the mixture was kept at

${ }^{3}$ Kimble Glass Co., Vineland, N. J. $37^{\circ} \mathrm{C}$. for one hour. One-tenth cc. of the heparinized blood and $0.1 \mathrm{cc}$. of a $1: 10$ dilution in sterile meat infusion broth ( $\mathrm{pH} \mathrm{7.8)}$ of an 18-hour culture of pneumococci in pneumococcus broth were then mixed in a $9 \times 135 \mathrm{~mm}$. test tube. The tubes were then sealed in a gas-oxygen flame and quickly placed upright in a water bath at $37^{\circ} \mathrm{C}$. for 5 minutes. The tubes were then kept for one hour at $37^{\circ} \mathrm{C}$. in a device which rotated them end over end 35 times per minute. A drop of the blood-pneumococcus mixture was then spread on a glass slide and stained with Wright's stain. The first 100 polymorphonuclear neutrophilic leukocytes encountered were examined for the presence of engulfed pneumococci. The phagocytic index was taken as the total number of intracellular diplococci divided by 100 . The phagocytic index for type one pneumococci, strain S.V.1, and for type two pneumococci, strain D39, was determined each week as a rule.

The stock cultures of the two strains of pneumococci used in the tests were continuously incubated at $37^{\circ} \mathrm{C}$. and were subcultured every 24 hours by adding $0.1 \mathrm{cc}$. of culture to $8 \mathrm{cc}$. of pneumococcus broth containing $0.1 \mathrm{cc}$. of normal rabbit blood. Each strain was passed at weekly intervals to a mouse by the intraperitoneal route and recovered from the blood of the heart 3 days before use in the tests. Both strains remained of uniform virulence so that a $10^{-6}$ dilution of culture was fatal for mice in approximately 24 hours. The bacterial colonies were always smooth.

A total leukocyte count of each sample of heparinized blood was made but there was no discernible relationship between the total leukocyte count and the phagocytic index. In no instance was a frank leukocytosis encountered.

CONTROL OBSERVATIONS IN NORMAL SUBJECTS

Certain observations served as controls for the studies in the patients on vitamin deficient diets. 
(a) In order to evaluate the significance of changes in titer in the test subjects, it was necessary to obtain parallel determinations of the same nature in normal individuals. Four persons from the laboratory were selected because they habitually consumed entirely adequate, average diets. Over a period of 34 weeks, at weekly intervals, tests for the influenza virus inactivating substance and lysozyme content of nasal secretions were conducted and monthly samples of serum were obtained for titration of neutralizing antibody to influenza virus (Figure 2). These materials were tested each week, together with similar material from all patients under investigation at the time. It was found that the results of each test in each individual tended, despite distinct variations, to remain at a characteristic high, intermediate or low level.

Each of the four subjects while under observation suffered his usual number of common colds. The presence of these infections was in no way reflected in the results of the tests nor was there any obvious relation between the immunological activity of the materials tested and the occurrence of the colds.

A single observation of great interest was made in Subject R. M. In the 26th week, when the subject was in the period of invasion of measles, no influenza virus inactivating substance was detected in the nasal secretions, although 1 week previously and 2 weeks later it was present in high titer.

(b) The phagocytic indices of the blood of three normal persons against pneumococci were determined each week. These tests were followed through periods of 8 weeks, 7 months and 8 months, respectively (Table III). Under the conditions of study, considerable fluctuation in the results was noted but no indication that the variations were due to modifications of bacterial virulence was obtained. The fluctuations were never uniform in all tests done at a given time but rather appeared to represent individual variations. On several occasions the accuracy of the technique was checked by treating two portions of the same sample of heparinized blood as separate specimens throughout the test. The resultant phagocytic indices were essentially the same. The conclusion was reached that the variations seen were related principally to unknown factors in the
TABLE III

Phagocytic indices of blood from three normal persons for type one and type two pneumococci

\begin{tabular}{|c|c|c|c|c|c|c|c|}
\hline \multicolumn{2}{|c|}{ Date } & \multicolumn{2}{|c|}{$\begin{array}{l}\text { Subject } \\
\text { A.E.F. }\end{array}$} & \multicolumn{2}{|c|}{$\begin{array}{l}\text { Subject } \\
\text { S.M. }\end{array}$} & \multicolumn{2}{|c|}{$\begin{array}{l}\text { Subject } \\
\text { E.M. }\end{array}$} \\
\hline & & $\begin{array}{c}\text { Type } \\
\text { one }\end{array}$ & $\begin{array}{l}\text { Type } \\
\text { two }\end{array}$ & $\begin{array}{c}\text { Type } \\
\text { one }\end{array}$ & $\begin{array}{c}\text { Type } \\
\text { two }\end{array}$ & $\begin{array}{c}\text { Type } \\
\text { one }\end{array}$ & $\begin{array}{c}\text { Type } \\
\text { two }\end{array}$ \\
\hline $\begin{array}{l}\text { October } \\
\text { October } \\
\text { October } \\
\text { October } \\
\text { October } \\
\text { October } \\
\text { October } \\
\text { October } \\
\text { October } \\
\text { November } \\
\text { November } \\
\text { November } \\
\text { November } \\
\text { November } \\
\text { November } \\
\text { December } \\
\text { December } \\
\text { December } \\
\text { December } \\
\text { December } \\
\text { January } \\
\text { January } \\
\text { January } \\
\text { January } \\
\text { February } \\
\text { February } \\
\text { February } \\
\text { March } \\
\text { March } \\
\text { March } \\
\text { March } \\
\text { April } \\
\text { April } \\
\text { April } \\
\text { April } \\
\text { April } \\
\text { May } \\
\text { May } \\
\text { May } \\
\text { May } \\
\text { June } \\
\text { June }\end{array}$ & $\begin{array}{r}8,1940 \\
10,1940 \\
15,1940 \\
16,1940 \\
17,1940 \\
22,1940 \\
24,1940 \\
29,1940 \\
31,1940 \\
5,1940 \\
7,1940 \\
14,1940 \\
20,1940 \\
27,1940 \\
29,1940 \\
4,1940 \\
10,1940 \\
17,1940 \\
24,1940 \\
31,1940 \\
7,1941 \\
14,1941 \\
21,1941 \\
28,1941 \\
4,1941 \\
18,1941 \\
25,1941 \\
4,1941 \\
11,1941 \\
18,1941 \\
25,1941 \\
1,1941 \\
8,1941 \\
15,1941 \\
22,1941 \\
29,1941 \\
6,1941 \\
13,1941 \\
20,1941 \\
27,1941 \\
3,1941 \\
10,1941 \\
\end{array}$ & \begin{tabular}{|l|}
0.04 \\
0.05 \\
0.03 \\
0.01 \\
0.02 \\
\\
1.04 \\
0.24 \\
0.10 \\
0.04 \\
0.15 \\
0.10 \\
0.02 \\
0.10 \\
0.03 \\
0.06 \\
0.02 \\
0.13 \\
0.17 \\
0.16 \\
0.50 \\
0.03 \\
1.20 \\
0.82 \\
0.49 \\
0.75 \\
0.40 \\
0.69 \\
0.10 \\
0.28 \\
0.26
\end{tabular} & $\begin{array}{l}5.06 \\
0.05 \\
0.11 \\
1.10 \\
3.01 \\
\\
7.05 \\
0.29 \\
0.98 \\
0.83 \\
0.47 \\
\\
0.91 \\
6.70 \\
0.76 \\
1.61 \\
0.99 \\
1.08 \\
2.50 \\
0.21 \\
0.86 \\
0.90 \\
0.67 \\
0.34 \\
1.97 \\
1.09 \\
3.26 \\
0.37 \\
1.83 \\
4.44 \\
0.81 \\
1.32 \\
0.88 \\
1.32 \\
3.70 \\
0.50 \\
2.70\end{array}$ & $\begin{array}{l}0.02 \\
0.00 \\
0.03 \\
0.03 \\
0.03 \\
\\
0.20 \\
0.04 \\
0.04 \\
0.07 \\
0.02 \\
0.00 \\
0.05 \\
\\
0.04 \\
0.01 \\
0.01 \\
0.14 \\
0.13 \\
0.34 \\
0.05\end{array}$ & $\begin{array}{l}1.22 \\
0.29 \\
0.44 \\
0.29 \\
0.19 \\
0.18 \\
0.09 \\
0.15 \\
0.10 \\
0.22 \\
0.18 \\
0.32 \\
0.37 \\
0.28 \\
0.37 \\
1.04 \\
0.04 \\
\\
0.62 \\
0.17 \\
0.63 \\
0.83 \\
0.32 \\
2.14 \\
0.36\end{array}$ & $\begin{array}{l}0.26 \\
0.93 \\
0.58 \\
0.55 \\
0.15 \\
2.87\end{array}$ & \begin{tabular}{|l}
3.26 \\
0.54 \\
0.84 \\
0.53 \\
0.23 \\
0.19
\end{tabular} \\
\hline
\end{tabular}

blood itself which influenced the phagocytic activity.

\section{EXPERIMENTAL OBSERVATIONS}

(a) The influence of changes in the blood plasma levels of vitamin $A$ and vitamin $C$ upon immunological phenomena

Immunological studies were made at regular intervals on each of two patients who were under approximately the same experimental conditions. In the course of these studies definite changes were produced in the plasma levels of vitamin A ind vitamin $C$. In addition, tests were made upon 
suaret as.
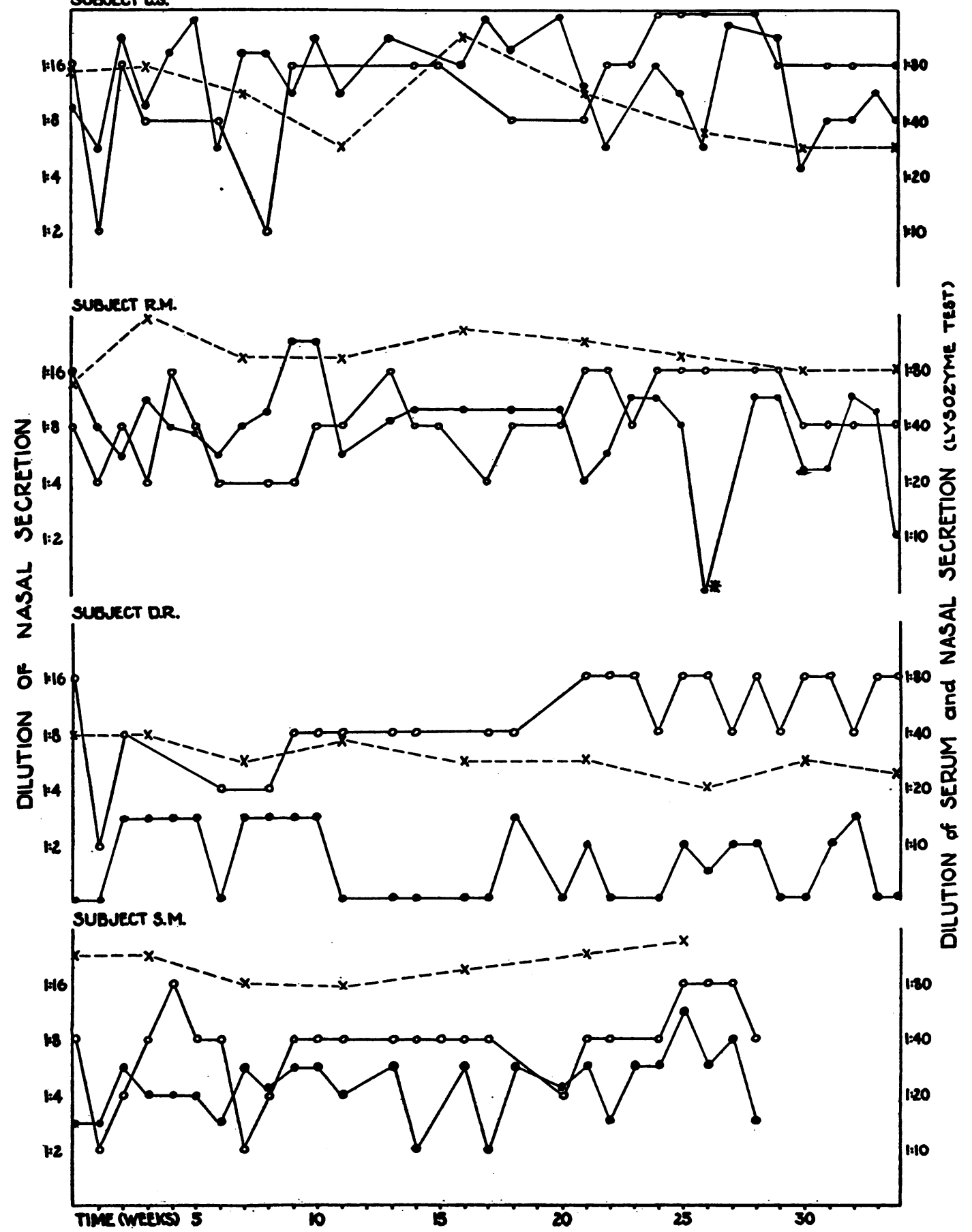

Fig. 2. Results of Tests for Influenza Virus Inactivating Substance in Nasal Secretions (- - ), Influenza Virus Neutralizing Antibody in Blood Serum $(X---X)$ and Lysozyme in Nasal Secretions ( $\mathrm{O}-\mathrm{O}$ ) of Four Normal Subjects as Determined at Weekiy INTERVALS

* Subject in the period of invasion of measles. 
materials obtained from each patient before and several hours after the administration of a dose of cod liver oil concentrate sufficient to cause a marked rise in the plasma level of vitamin A.

$W . W$., a 50-year-old white male, was admitted to the hospital on September 6,1940. He had lost 35 pounds of weight during the preceding year and had suffered from nervousness and tremors. He was undernourished and had generalized arteriosclerosis.

A high caloric diet was given for 8 days at the end of which time analysis of the blood plasma revealed 0.5 mgm. per cent of vitamin C, 88 U.S.P. units of vitamin A per $100 \mathrm{cc}$. and $0.13 \mathrm{mgm}$. per cent of carotene.

On September 17, a 90-day period of observation was begun. The patient was placed on the vitamin A deficient diet supplemented daily with $200 \mathrm{mgm}$. ascorbic acid, $10 \mathrm{mgm}$. thiamine chloride, $50 \mathrm{mgm}$. nicotinic acid, 15 grams dried brewers' yeast and 1.2 grams ferrous sulphate. This regime was continued for 32 days during which time the plasma levels of vitamin A ranged between 75 and 88 U.S.P. units per $100 \mathrm{cc}$. while the plasma carotene fell progressively to a low level of $0.075 \mathrm{mgm}$. per cent. By the 10 th day, as a result of the administration of vitamin $\mathrm{C}$, the plasma level had risen to $1.87 \mathrm{mgm}$. per cent and the concentration in the white blood cell-platelet layer was $24 \mathrm{mgm}$. per $100 \mathrm{grams}$.

The patient was discharged from the hospital on the 32nd day with instructions to eat a regular diet supplemented daily with 300,000 U.S.P. units of vitamin A in the form of a cod liver oil concentrate. The other dietary supplements were discontinued. The patient returned weekly for further observations. This regime was continued for the final 58 days of the study. As a result of the large intake of vitamin A, the plasma level increased to 143 U.S.P. units per $100 \mathrm{cc}$. by the 44th day at which time the daily dose of vitamin $\mathrm{A}$ was reduced to 100,000 U.S.P. units. By the 58th day, the plasma vitamin A content had decreased to 75 U.S.P. units per $100 \mathrm{cc}$. On the $82 \mathrm{nd}$ day, the patient was given a large dose of cod liver oil $(300,000$ U.S.P. units of vitamin A). This raised the plasma level of vitamin $A$ from an initial value of 88 to a value of 393 U.S.P. units per $100 \mathrm{cc}$. in 5 hours. After this the usual daily dose of 100,000 U.S.P. units of vitamin A was resumed. The diet probably contained inadequate amounts of vitamin C because the plasma level decreased progressively to 0.21 mgm. per cent. On the 83rd day, he was again placed on $200 \mathrm{mgm}$. vitamin $\mathrm{C}$ daily and by the 90th day, the plasma level had risen to $1.73 \mathrm{mgm}$. per cent.

During the studies the patient gained approximately 10 pounds in weight.

T. O., a 60-year-old white male, was admitted to the hospital on September 17, 1940. His chief complaints were abdominal pain for 6 months, loss of 40 pounds of weight during the preceding year and weakness for 6 months. Although he had consumed no liquor for $21 / 2$ years, he had previously been a heavy drinker. His diet had been inadequate for 2 years, consisting mostly of oatmeal and some sort of stew. He took no milk, fruit or vegetables. He suffered frequently from the common cold. The patient weighed 146 pounds and did not appear ill. The skin was slightly icteric. The liver was enlarged, firm and tender and the abdominal veins were dilated. The urine contained bile and urobilin. The icteric index was 21 . Red blood cells numbered 5.8 million per cubic millimeter and the blood contained 13 grams hemoglobin per $100 \mathrm{cc}$. The plasma vitamin A was 25 U.S.P. units per $100 \mathrm{cc}$. and the plasma carotene was $0.06 \mathrm{mgm}$. per cent. No vitamin $\mathrm{C}$ was detected in the plasma. A diagnosis of cirrhosis of the liver was made.

Due to the low level of vitamin A in the plasma, this patient provided an opportunity to study the immunological phenomena while the plasma vitamin A was kept at a low level and then to observe the possible effects of the administration of cod liver oil in amounts sufficient to raise the plasma level of vitamin A to normal.

A 175-day period of observation was begun on September 24 when the patient was placed on the vitamin A deficient diet supplemented daily with $20 \mathrm{mgm}$. thiamine chloride, $200 \mathrm{mgm}$. nicotinic acid and 30 grams dried brewers' yeast. This vitamin A deficient regime was continued for 26 days during which time the plasma level of vitamin A was never above 45 U.S.P. units per 100 cc. and the plasma level of carotene was never above $0.080 \mathrm{mgm}$. per cent. At the beginning of this 26-day period, there was still no vitamin $C$ in the plasma and the white blood cell-platelet layer contained only $5 \mathrm{mgm}$. per 100 grams. One thousand $\mathrm{mgm}$. of vitamin $C$ were given daily from the 2 nd to the 6 th day, at which time the plasma content of vitamin $\mathrm{C}$ had risen to $1.05 \mathrm{mgm}$. per cent and the concentration in the white blood cellplatelet layer was $25 \mathrm{mgm}$. per 100 grams. From the 6 th to the 26 th day, the patient received $200 \mathrm{mgm}$. vitamin $\mathrm{C}$ daily and the plasma level of vitamin $\mathrm{C}$ remained within the normal range.

From the 26th to the 115th day, the vitamin A deficient diet, the daily supplements of the vitamin B complex and $200 \mathrm{mgm}$. of vitamin $C$ daily were continued as before but adequate amounts of vitamin $A$ in the form of a cod liver oil concentrate were given daily. From the 26th to the 31st day, 300,000 U.S.P. units of vitamin A were given daily. By the 29th day, the plasma level of vitamin A had risen to 118 U.S.P. units per $100 \mathrm{cc}$. but the plasma carotene level was still low, $0.050 \mathrm{mgm}$. per cent. Because of diarrhea, the cod liver oil was discontinued on the 31st day. From the 45th to the 73rd day, 100,000 U.S.P. units of vitamin A were given daily and the plasma levels varied from 75 to 97 U.S.P. units per $100 \mathrm{cc}$. From the $73 \mathrm{rd}$ to the 115 th day, the daily dose of vitamin A was increased to 200,000 U.S.P. units and during this period the plasma content varied from 75 to 157 U.S.P. units per 100 cc. Meanwhile, the plasma levels of carotene progressively decreased to $0.015 \mathrm{mgm}$. per cent, probably because of the absence of carotenecontaining foods from the diet. From the 26th to the 115th day, the plasma and white blood cell-platelet levels of vitamin $\mathrm{C}$ remained within the normal range due to 
the administration of adequate amounts of the vitamin daily.

From the 115th to the 175th day, the patient continued to receive 200,000 U.S.P. units of vitamin A daily plus the vitamin B complex but all sources of vitamin C were removed from the diet and no supplements of vitamin $C$ were given. The plasma levels of vitamin $\mathrm{A}$ and carotene remained at their former values during this final period of study but the plasma level of vitamin C gradually fell to zero by the 175 th day.

On the 112th day, a dose of cod liver oil containing 300,000 U.S.P. units of vitamin A was given and the plasma level of the vitamin rose from a fasting value of 153 to 815 U.S.P. units per $100 \mathrm{cc}$. in 5 hours and then fell to 157 U.S.P. units per $100 \mathrm{cc}$. in the next 20 hours.

During the studies the patient suffered several attacks of the common cold; two of them occurred while he was taking vitamin $A$ and vitamin $C$. The jaundice and $a b-$ dominal pain gradually disappeared. The patient gained approximately 25 pounds in weight.

Although marked changes were produced and maintained in the plasma levels of vitamin $A$ and vitamin $C$ by the addition or removal of these substances from the diet, noteworthy alterations in the results of the immunological tests were not observed (Figures 3 and 4). Furthermore, abrupt rises in the plasma content of vitamin A were induced by the administration of a large dose of this vitamin. Materials for the immunological tests were obtained from each patient just before the administration of the vitamin $\mathrm{A}$, at a time when the plasma levels of this vitamin were normal, and again 5 hours later when the levels were 393 and 815 U.S.P. units per 100 cc., respectively. In neither instance were the results of the immunological tests appreciably influenced by the abrupt increase in the vitamin A content of the plasma.

\section{(b) The influence of vitamin $C$ deficiency upon immunological phenomena}

Immunological studies were made at regular intervals in each of two patients who were kept on the regime deficient in vitamin $\mathrm{C}$ until they were thoroughly depleted of the vitamin and who were then given amounts of vitamin $\mathrm{C}$ adequate to restore the plasma and white blood cell-platelet levels to normal.

$J$. $M$., a 54-year-old white male, was admitted to the hospital on October 31, 1940. His chief complaint was pain in the left upper portion of the chest anteriorly and in the left shoulder and arm. These pains were due to a mild arthritis of the dorsal spine and left shoulder joint.
The patient was in good condition and well nourished. The plasma vitamin $C$ was $0.21 \mathrm{mgm}$. per cent on November 27.

A 130-day period of observation was begun on November 29 , when the patient was placed on the vitamin $C$ deficient diet supplemented daily with $20 \mathrm{mgm}$. thiamine chloride, $100 \mathrm{mgm}$. nicotinic acid, $2 \mathrm{mgm}$. riboflavin, 30 grams dried brewers' yeast and 100,000 U.S.P. units of vitamin $\mathrm{A}$ in the form of a cod liver oil concentrate. The plasma level of vitamin $C$ fell gradually and reached zero by the 34th day, at which time the concentration of ascorbic acid in the white blood cell-platelet layer was 10 mgm. per 100 grams. Vitamin $C$ was absent from the plasma from the 34th to the 97th day and during this interval of 63 days the amount of ascorbic acid in the white blood cell-platelet layer varied from 3 to $9 \mathrm{mgm}$. per 100 grams.

From the 97th day to the end of the study (a period of 33 days), $200 \mathrm{mgm}$. of vitamin $\mathrm{C}$ were given by mouth daily but the regime was otherwise unchanged. On the 102nd day, no vitamin $C$ was present in the plasma and the amount of ascorbic acid in the white blood cell-platelet layer was only $5 \mathrm{mgm}$. per 100 grams. Thereafter, the plasma level of vitamin C rose slowly to $0.88 \mathrm{mgm}$. per cent by the 130th day, at which time the concentration in the white blood cell-platelet layer was $20 \mathrm{mgm}$. per 100 grams.

Throughout the study the patient received large daily doses of vitamin A. This resulted in a rise in the plasma level of vitamin A from an initial value of 105 U.S.P. units per $100 \mathrm{cc}$. to values which were usually above 150 and frequently exceeded 300 U.S.P. units per 100 cc. The diet was deficient in foods containing carotene so that, in spite of the high levels of vitamin A in the plasma and the large daily doses of cod liver oil, the plasma carotene level fell from an original value of $0.135 \mathrm{mgm}$. per cent to $0.040 \mathrm{mgm}$. per cent on the 88th day and was only $0.065 \mathrm{mgm}$. per cent on the 130 th day.

Signs or symptoms of scurvy did not appear although vitamin $C$ was absent from the plasma for 63 consecutive days and the amount of ascorbic acid in the white blood cell-platelet layer was reduced to $3 \mathrm{mgm}$. per 100 grams. This observation was not unexpected since Crandon $e t$ al. (13) and Ralli and Sherry (14) have also reported instances in which vitamin $C$ has been absent from the plasma for considerable periods of time without clinical evidence of scurvy. In Crandon's report (13), a diet deficient in vitamin $C$ was continued for 140 days before the first clinical signs of scurvy appeared. In the present case there was little doubt that the patient's tissues had been thoroughly depleted of vitamin $\mathrm{C}$ as $5900 \mathrm{mgm}$. of the vitamin were required to resaturate the plasma and white blood cell-platelet layer.

The patient gained approximately 33 pounds in weight during the study, thus emphasizing the adequacy of the diet in other respects.

The depletion of vitamin $C$ in this patient and the subsequent saturation of the tissues by the ad- 

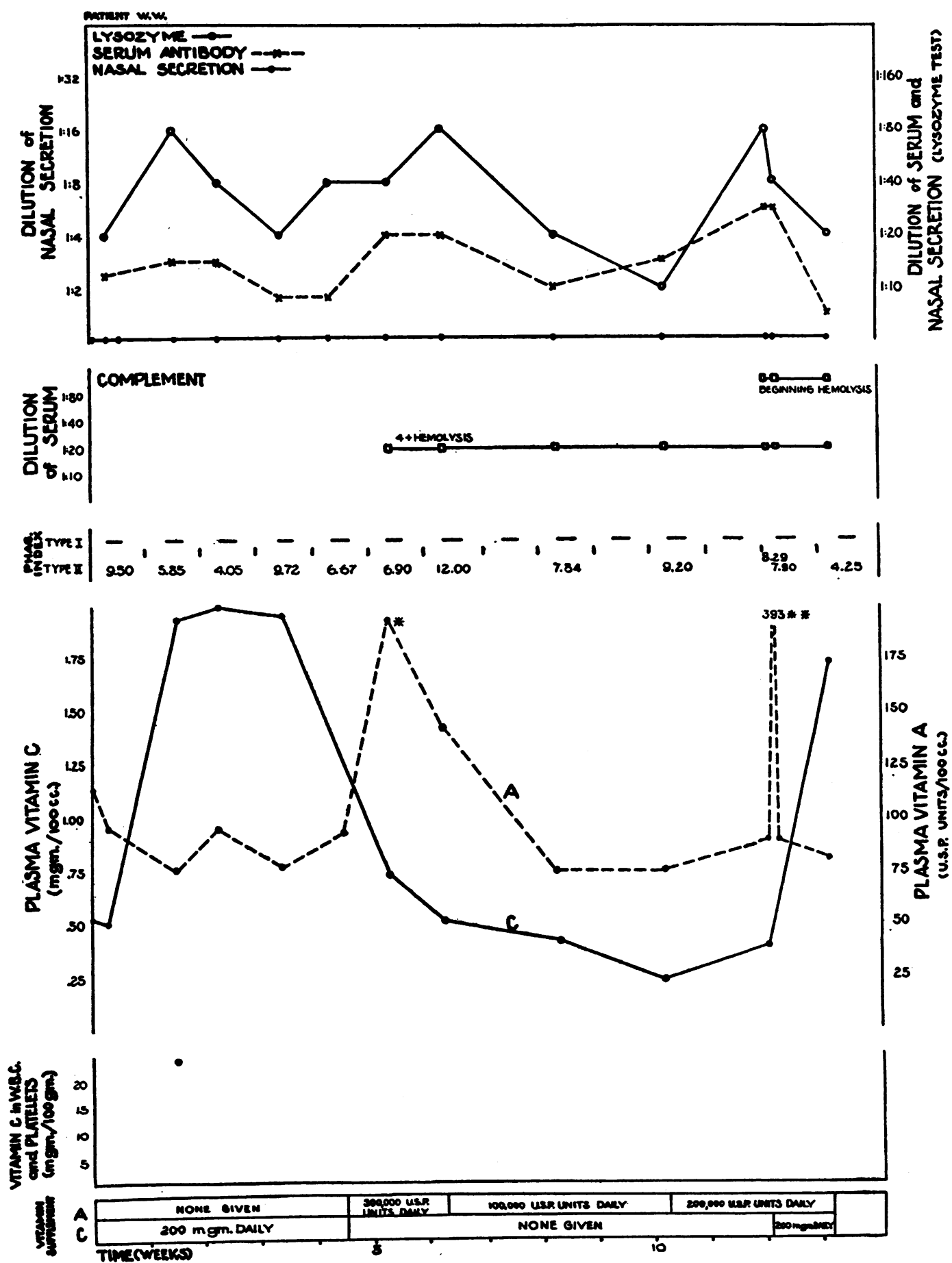

Fig. 3. Results of Immunological Tests in Patient W. W.

* This determination was made 2 hours after the patient had taken cod liver oil and does not represent the fasting level of vitamin A.

** This figure is the level of vitamin A 5 hours after the administration of 300,000 U.S.P. units of vitamin $A$. The immunological tests were performed on materials obtained immediately previous to and 5 hours after the administration of the vitamin $\mathrm{A}$. 

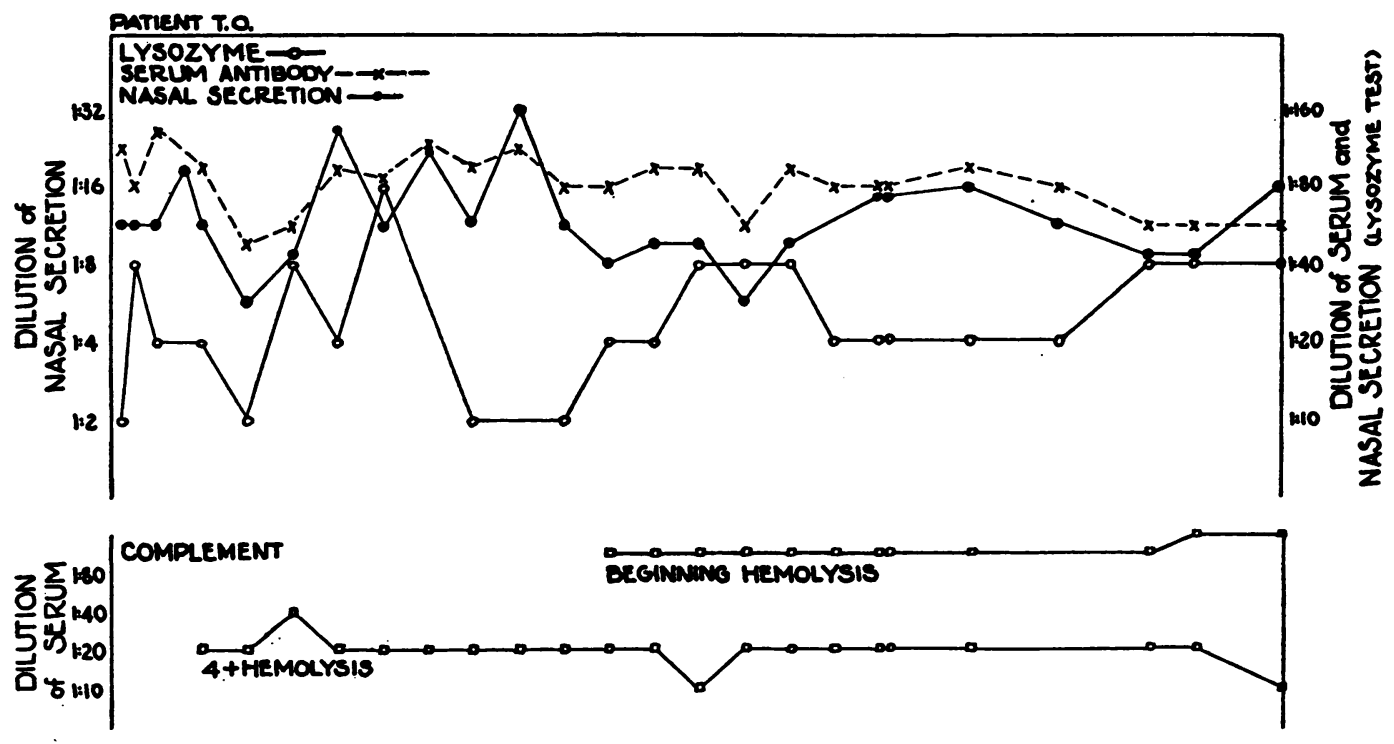

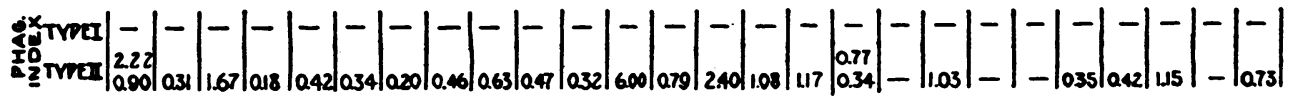
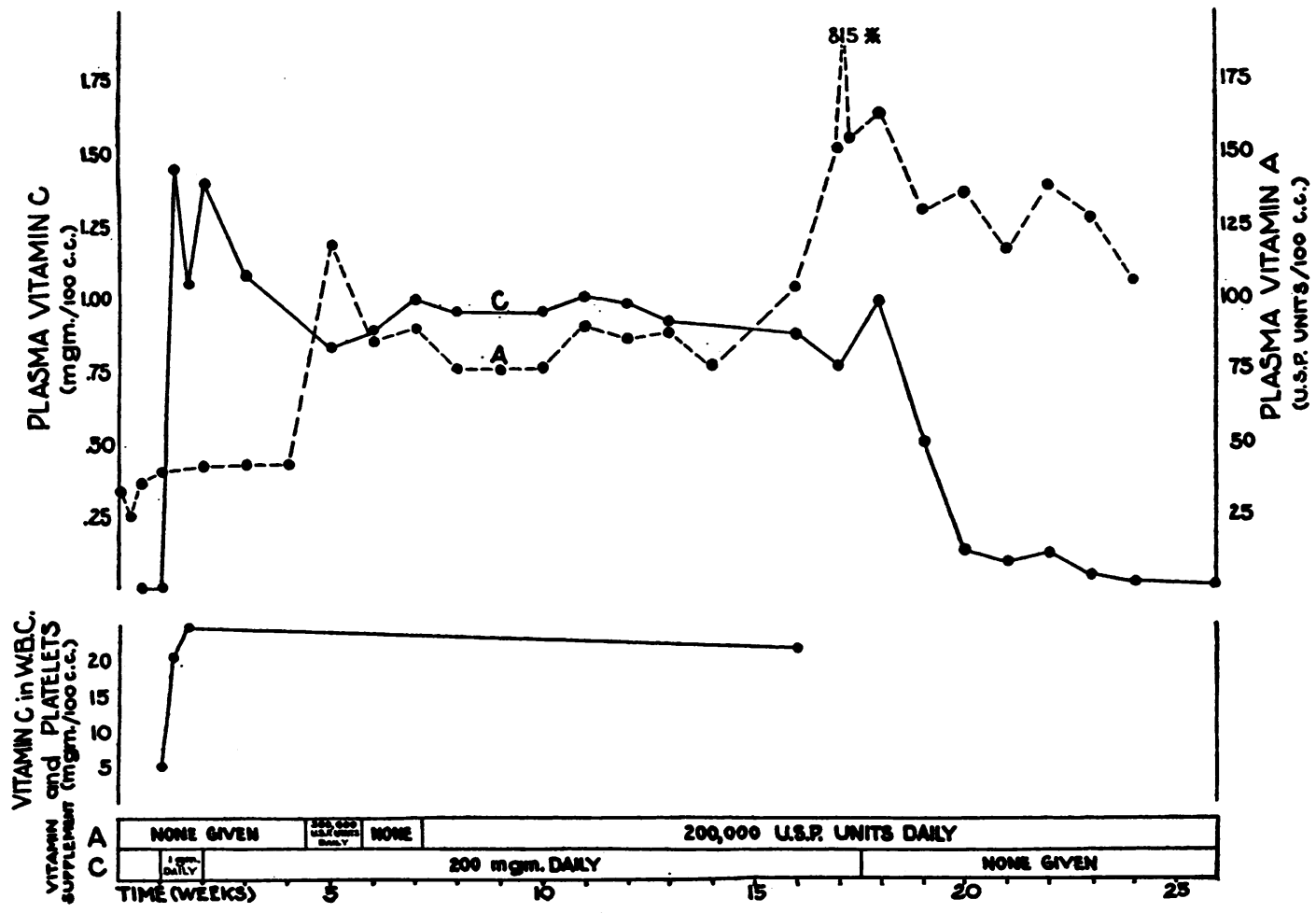

Fig. 4. Results of Immunological Tests in Patient T. O.

* This figure is the level of vitamin A 5 hours after the administration of 300,000 U.S.P. units of vitamin A. The immunological tests were performed on materials obtained immediately previous to and 5 hours after the administration of the vitamin A. 
ministration of ascorbic acid produced no significant alterations in the results of the immunological tests (Figure 5). During the final 5 weeks of the study, when the patient was receiving $200 \mathrm{mgm}$. of vitamin $\mathrm{C}$ daily and the plasma levels were progressively increasing, determinations of the influenza virus inactivating substance in the nasal secretions yielded one result definitely below the average and two results clearly higher than the average. These variations appear to have little significance because fluctuations of equal or greater magnitude were frequently demonstrated in the titers for this substance in nasal secretions obtained from normal persons (Figure 2). Five of the final seven phagocytic indices for type two pneumococci exceeded the upper limits of the values previously observed. This increase in the phagocytic power of the blood was probably unrelated either to the vitamin $\mathrm{C}$ deficiency or to the subsequent saturation of the tissues with ascorbic acid because the indices were significantly increased before the patient was given vitamin $\mathrm{C}$ and there was no comparable increase in the indices for type one pneumococci. Furthermore, it was demonstrated by means of the mouse protection test that serum obtained during the 21st week of observation, when the phagocytic index for type two pneumococci was 7.52, contained type specific antibodies for type two pneumococci, whereas none was present in serum obtained during the 11th week. The test was performed by testing each specimen of serum with three dilutions of culture of pneumococci, namely, $10^{-4}, 10^{-5}, 10^{-6}$. Three mice were injected with each mixture of serum and pneumococci. All mice receiving mixtures of pneumococci and serum taken in the 11th week died. All mice receiving mixtures of serum taken in the 21st week and pneumococci in a dilution of $10^{-4}$ and $10^{-5}$ also died but two of the three animals receiving the $10^{-6}$ dilution of pneumococci (10 lethal doses per animal) survived. The elaboration of type specific antibody was most probably the result of an actual stimulus by the specific antigen.

Of special interest was the observation that the amount of complement in the blood serum as measured by the technique described above was not decreased in this patient during the period of vitamin C deficiency. This confirms the report of Crandon et al. (13) who found no decrease in serum complement despite a severe depletion of vitamin C. Others $(15,16)$ have stated that a decrease in complement parallels a deficiency in vitamin $C$.

$L . N$., a 34-year-old negro male with a history of alcoholism, was admitted to the hospital on April 15, 1941. $\mathrm{He}$ had an acute alcoholic gastritis but it subsided in a few days. He was in a good state of nutrition.

A 47-day period of observation was begun on April 24 when the patient was placed on the vitamin $C$ deficient diet with daily supplements of $10 \mathrm{mgm}$. thiamine chloride, $100 \mathrm{mgm}$. nicotinic acid and 30 grams of dried brewers' yeast. On the 5th day, daily supplements of 100,000 U.S.P. units of vitamin $A$ in the form of a cod liver oil concentrate were begun. This regime was continued for 40 days and during this period the plasma level of vitamin $\mathrm{C}$ remained at zero and the concentration of ascorbic acid in the white blood cell-platelet layer varied between 6 and 9 mgm. per 100 grams.

On the 40th day, daily supplements of $500 \mathrm{mgm}$. of vitamin $C$ were added. By the 47 th day, the plasma vitamin $C$ had risen to $1.25 \mathrm{mgm}$. per cent and the level in the white bood cell-platelet layer had increased to a value of $33 \mathrm{mgm}$. per 100 grams.

The amount of vitamin $A$ in the plasma ranged from 78 to 195 U.S.P. units per $100 \mathrm{cc}$. during the 47 days of observation while the amount of carotene in the plasma decreased from an initial value of $0.080 \mathrm{mgm}$. per cent to a final value of $0.065 \mathrm{mgm}$. per cent.

On the 27th day, the patient developed an acute pharyngitis with cervical lymphadenopathy and fever of $102.6^{\circ}$ F. Beta hemolytic streptococci, Lancefield group A, were isolated from the pharynx. The course of the illness was not unusual despite the deficiency in vitamin $C$ and the patient was well by the 33rd day. Only symptomatic treatment was used.

The deficiency of vitamin $C$ in this patient was severe. This was shown by the fact that the amount of vitamin C required to saturate the tissues $(3500 \mathrm{mgm}$.) was approximately the amount required to saturate the tissues of patients suffering from scurvy (17).

The patient gained 7 pounds in weight during the study.

At no time during the period of observation were the titers of lysozyme in the nasal secretions, the amounts of complement in the blood serum or the phagocytic indices of the blood for pneumococci altered to a significant degree (Figure 6). The fact that the phagocytic indices were not influenced either by the deprivation of vitamin $C$ or by the subsequent saturation of the tissues with the vitamin supports the impression that the increase in the phagocytic indices for type two pneumococci observed in the previous patient (J. M.) subjected to prolonged deprivation of vitamin $\mathrm{C}$ was unrelated either to the deficiency or to the administration of the vitamin. 

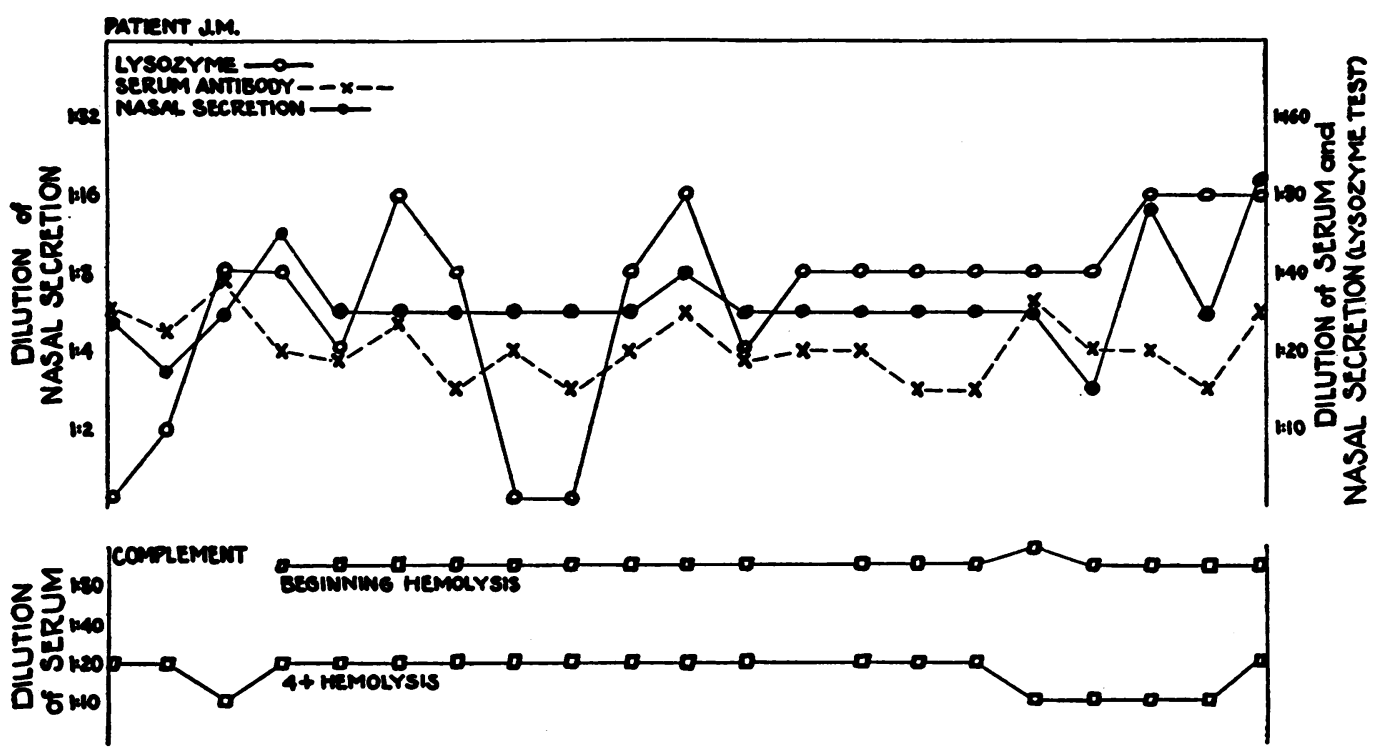

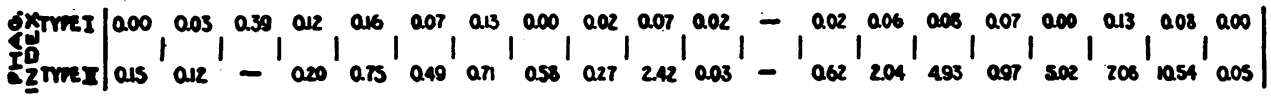
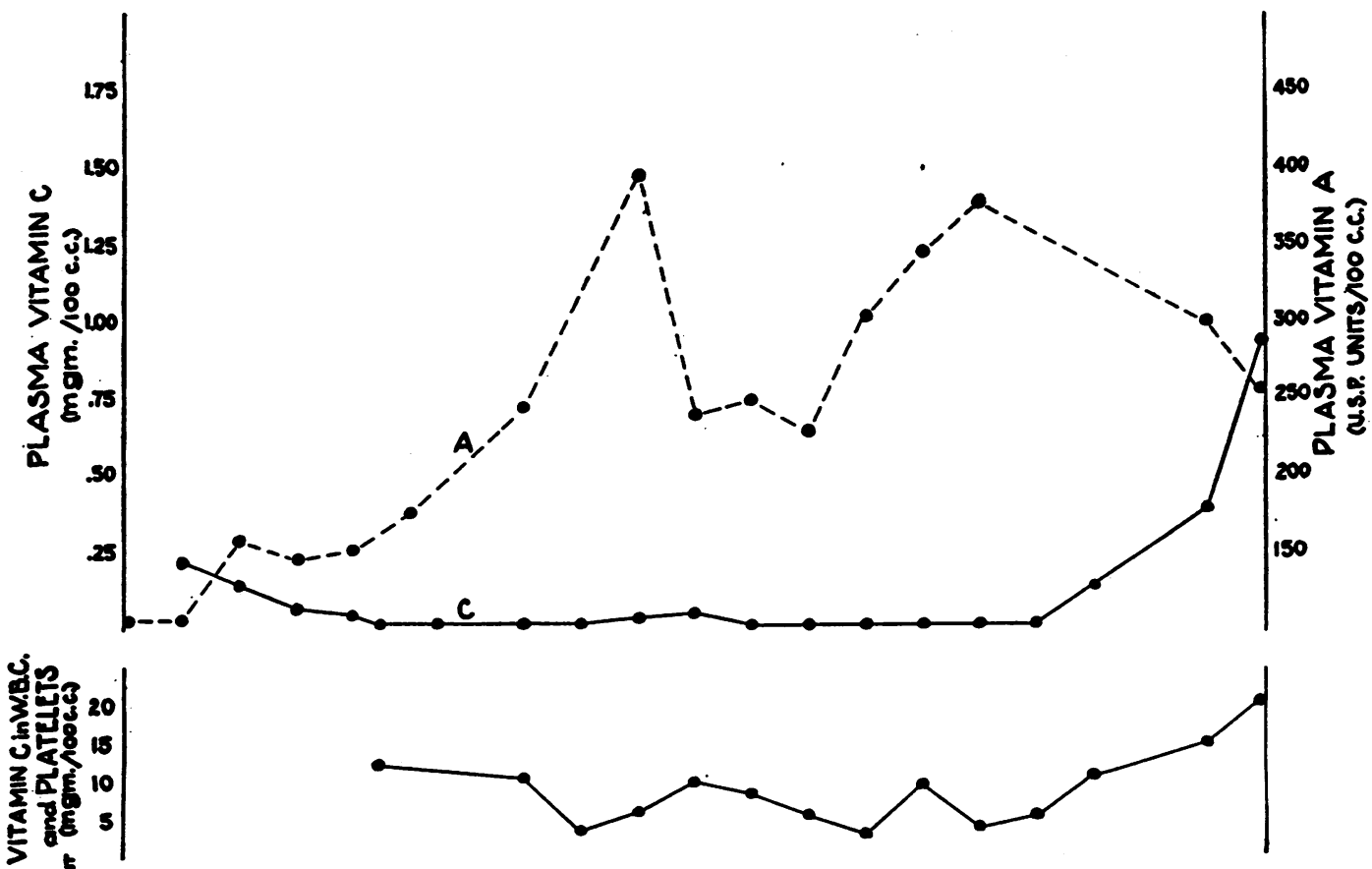

A

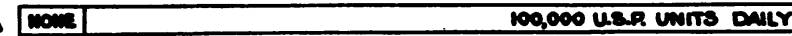

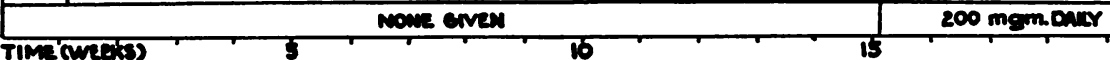

Fig. 5. Results of Immunological Tests in Patient J. M. 

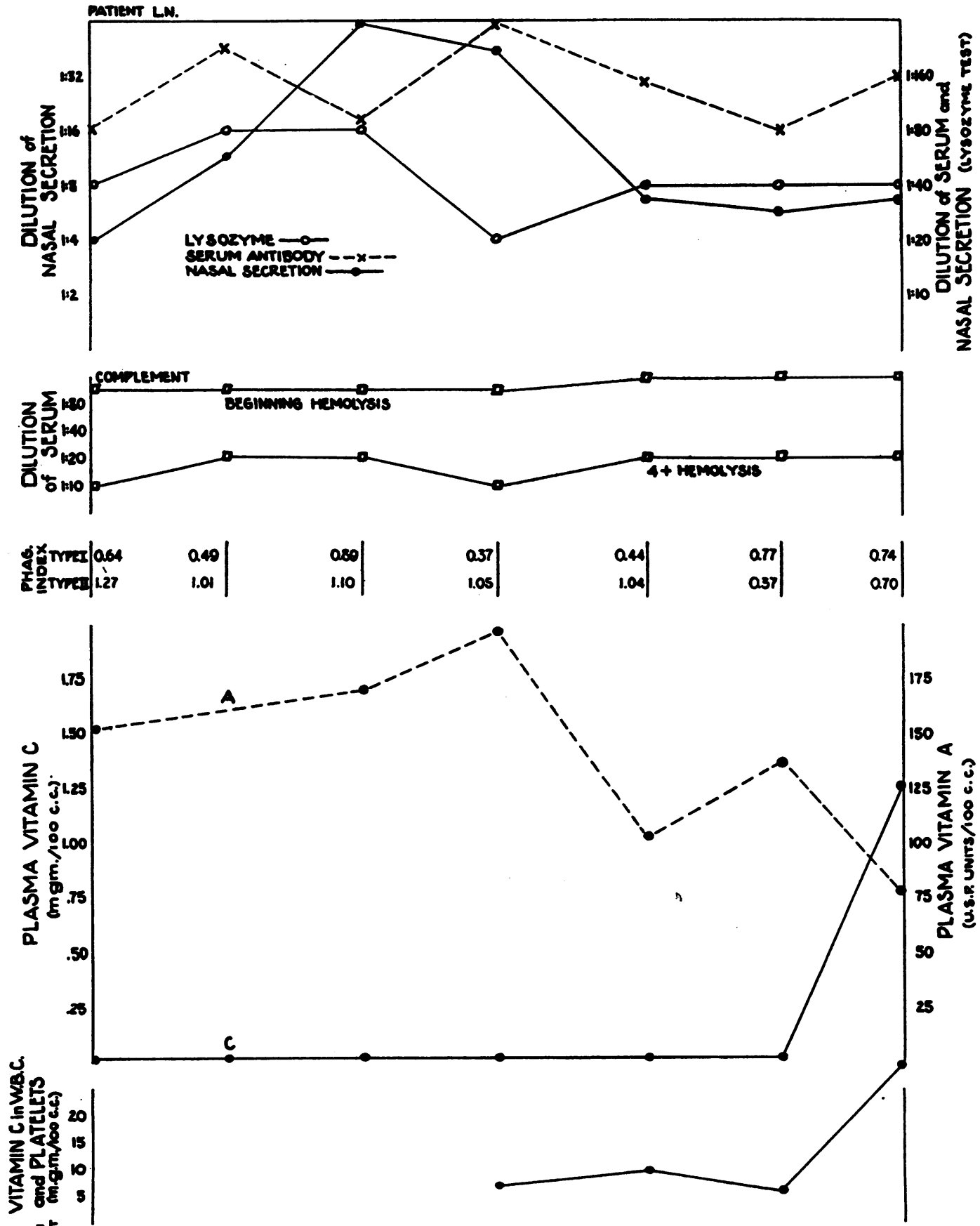

害

100,000 U.8.R. UNITS DanY

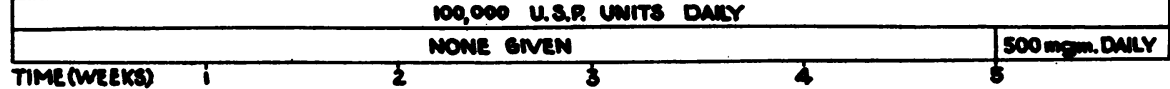

Fig. 6. Results of Immunological Tests in Patient L. N. 
On the other hand, the variations in the titer of influenza virus inactivating substance in the nasal secretions and of influenza virus neutralizing antibody in the serum were of interest. The titers increased during the first 3 weeks of observation, remained at a high level in the 4th week and fell to lower levels in the 5th and 6th weeks. These observations were not readily explained. That they were related either to the depletion of vitamin C or to the saturation of the tissues with the vitamin is not clear since the titers both rose and fell during the period when the amount of vitamin $\mathrm{C}$ in the blood was extremely small and were not influenced appreciably by the administration of $500 \mathrm{mgm}$. of ascorbic acid daily for one week. The amount of vitamin $\mathrm{A}$ in the plasma was within normal limits during the entire period of study. The attack of pharyngitis did not occur until the 4th week, at which time the titers were decreasing. It could be suggested that the increase in virus neutralizing titers was due to specific infection with influenza virus. There was no clinical evidence that such infection had occurred.

\section{(c) The influence of a diet deficient in vitamin $A$ upon immunological phenomena}

Immunological studies were made at regular intervals on a patient who was kept on a diet deficient in vitamin $A$ for 17 weeks and who was then given large amounts of vitamin A daily during the final 2 weeks of study. In addition, materials for the various immunological tests were obtained before and 3 hours after the initial administration of vitamin A immediately subsequent to the period of deprivation in order to test the immunological phenomena at a time when the plasma was flooded with the vitamin.

A. M., a 33-year-old white male, was admitted to the hospital on December 23, 1940. Except for an ankylosing arthritis of the spine and hip joints, he was normal and well nourished. On admission, the vitamin $C$ in the plasma was $0.09 \mathrm{mgm}$. per cent; the vitamin $A$ in the plasma was 135 U.S.P. units per $100 \mathrm{cc}$; the carotene in the plasma was $0.110 \mathrm{mgm}$. per cent.

A 126-day period of study was begun on January 28, when the patient was placed on the diet deficient in vitamin A with daily supplements of $10 \mathrm{mgm}$. thiamine chloride, $200 \mathrm{mgm}$. nicotinic acid, 30 grams of dried brewers' yeast and $200 \mathrm{mgm}$. vitamin C. Although this diet which was deficient in vitamin $A$ was continued for 112 days, the level of vitamin $A$ in the plasma never fell below the values observed in normal subjects.

From the 113th to the 126th day, a daily supplement of 100,000 U.S.P. units of vitamin A in the form of a cod liver oil concentrate was added but the fasting levels of vitamin $\mathrm{A}$ in the plasma determined at weekly intervals were not affected appreciably. However, the level of vitamin $A$ in the plasma determined subsequent to the period of deprivation and 3 hours after the initial dose of the vitamin did rise from a fasting value of 98 U.S.P. units per $100 \mathrm{cc}$. to 405 U.S.P. units per $100 \mathrm{cc}$. Three hours later it fell to a level of 310 U.S.P. units and was back again to a normal value of 123 U.S.P. units after 24 hours.

On the 7th day the daily supplement of vitamin $C$ was reduced to $100 \mathrm{mgm}$. but, despite the fact that this amount of ascorbic acid is known to be adequate (9), the level of vitamin $C$ in the plasma fell from $1.06 \mathrm{mgm}$. per cent and by the 70th day was $0.39 \mathrm{mgm}$. per cent. On the 105 th day, the daily supplement of vitamin $C$ was increased to $200 \mathrm{mgm}$. for 6 days. Although the level of vitamin $C$ in the plasma rose only to a value of $0.43 \mathrm{mgm}$. per cent, the concentration in the white blood cell-platelet layer was $22 \mathrm{mgm}$. per 100 grams.

The amount of carotene in the plasma fell progressively from an initial value of $0.095 \mathrm{mgm}$. per cent to a value of $0.025 \mathrm{mgm}$. per cent on the 126th day. This was probably due to the absence of carotene from the diet.

The patient remained well and gained 15 pounds in weight during the study. No manifestations of a deficiency in vitamin A were detected.

If the level of vitamin $\mathrm{A}$ in the plasma reflects the concentration of the vitamin in the tissues, this patient cannot be considered to have been depleted of vitamin A. The 17-week period on the regime deficient in vitamin A did not appreciably lower the level of the vitamin in the plasma. Furthermore, the response, as measured by the level of vitamin $\mathrm{A}$ in the plasma following the administration of 100,000 U.S.P. units of the vitamin subsequent to the period of deprivation, was similar to the response observed in normal subjects after the same dose (8). Granted that a definite deficiency in vitamin $\mathrm{A}$ was not produced in this patient, the fact remains that both during a prolonged period of deprivation of the vitamin and during a subsequent period of 2 weeks when the patient was given large doses of vitamin A daily, no noteworthy alterations in the results of the immunological tests were observed (Figure 7). Briefly stated, a period of 17 weeks on a diet deficient in vitamin A had no appreciable influence on the immunological reactions which were measured. 

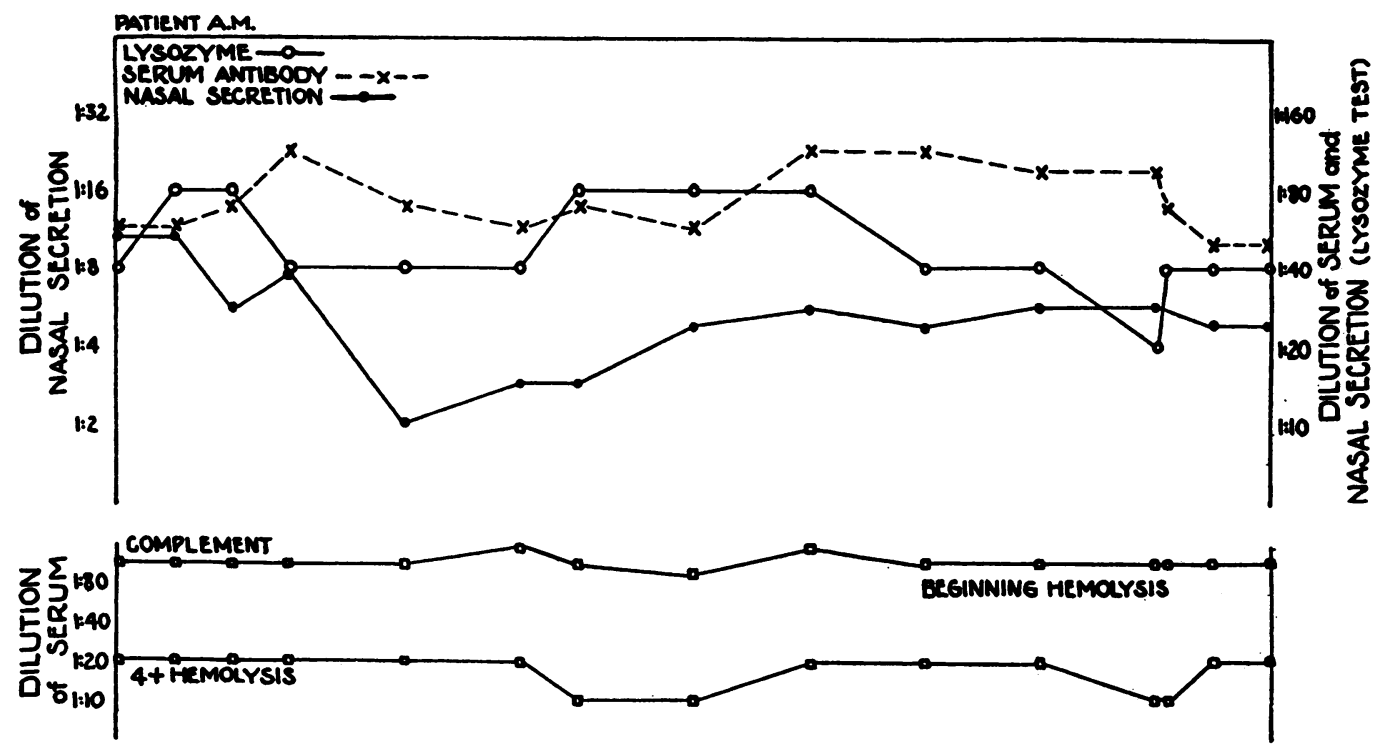

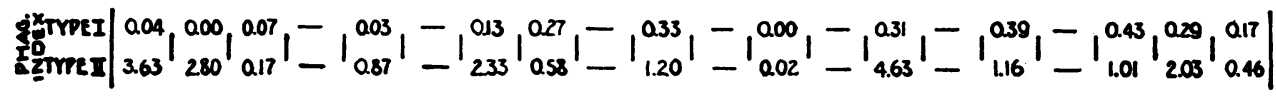
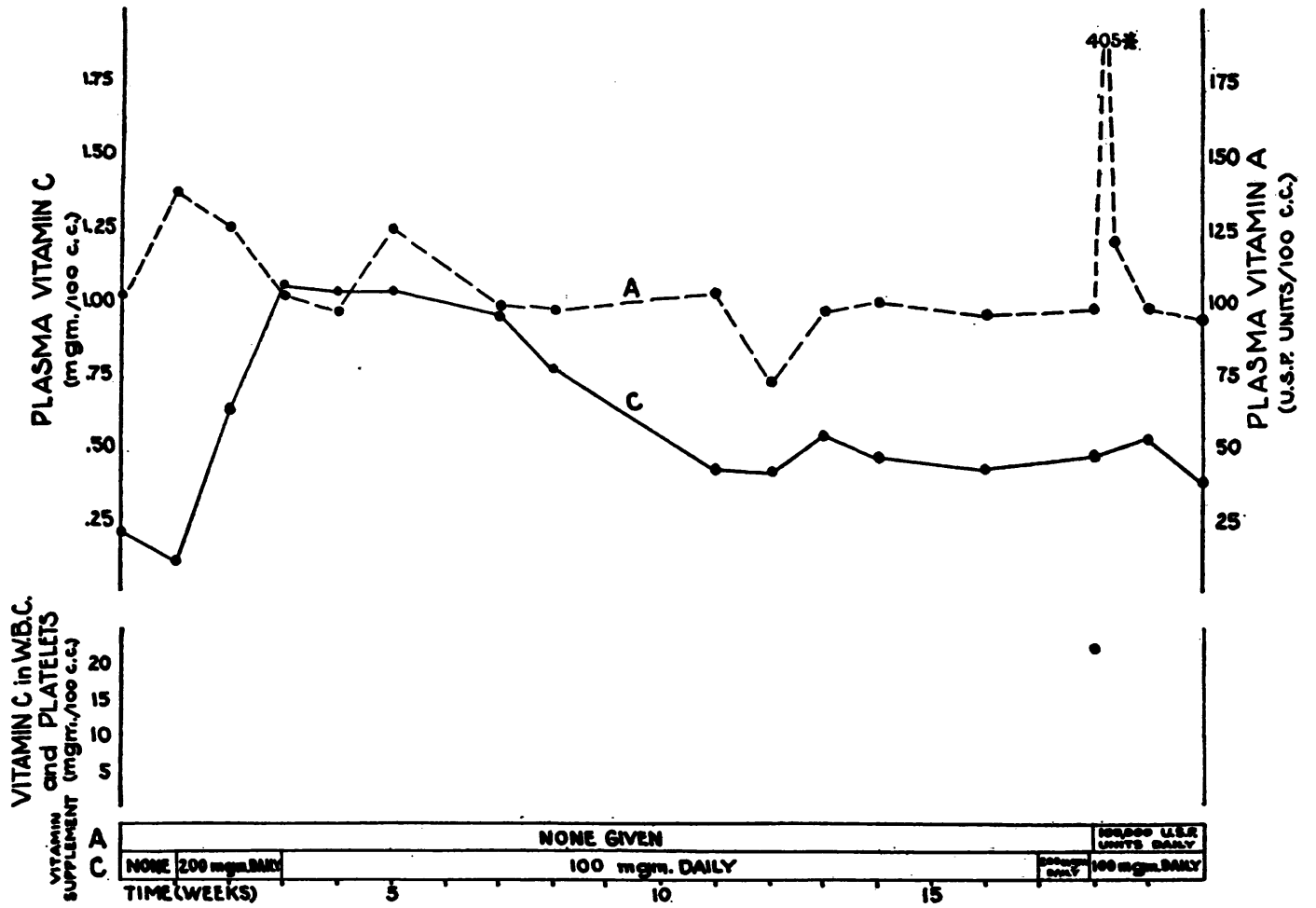

Fig. 7. Results of Immunological Tests in Patient A. M.

* This figure is the level of vitamin A 3 hours after the administration of 100,000 U.S.P. units of vitamin A. The immunological tests were performed on materials obtained immediately previous to and 3 hours after the administration of the vitamin A. 


\section{DISCUSSION}

The majority of studies (2) concerning the relation of vitamin deficiencies and resistance to infection are open to certain obvious criticisms. In the human subject most investigations have dealt with nutritional deficiency diseases which are rarely, if ever, attributable to deficiency of a single vitamin. In addition, most studies have only extended over a brief period of time and other dietary factors have not been adequately controlled. Moreover, the immunological examinations have usually considered but one phenomenon. In animal experiments, as for instance those reporting close correlation between complement activity and vitamin $\mathrm{C}$ content of the blood (18), the parallel loss in weight due to the cessation of eating has been disregarded. The plan of the present investigation has sought to eliminate these objections. All patients received diets adequate both in calories and essential foodstuffs; in addition, large amounts of vitamins were given daily excepting the specific vitamin, the influence of which was to be determined. The observations extended over relatively long intervals; the shortest period was 6 weeks, while the others lasted from 14 to 26 weeks. Under these conditions, repeated immunological determinations could be made in each phase of dietary modification and errors due to single observations were avoided. The patients were kept in the hospital, the diets were controlled so that all patients gained weight and the daily supplements of vitamin were accurately administered. Control observations of normal subjects on an average diet were similarly conducted. The immunological reactions studied included supposedly physiological or natural phenomena such as complement, lysozyme and pneumococcidal activity, together with apparently specific immune reactions to influenza virus. Thus the influence of pronounced and sustained shifts in the concentrations of vitamin $A$ or vitamin $C$ in the blood was more likely to be detected. These two vitamins were selected for study because they have received the most attention in the relation of vitamins to resistance.

Under the experimental conditions described no consistent parallelism between the amount of vita$\min \mathrm{A}$ or vitamin $\mathrm{C}$ in the blood and the degree of immunological activity has been observed.
Fluctuations in the titers of the various reactions occurred but they varied within narrow limits with relatively few exceptions. Nor were they essentially different from the variations noted in the normal controls. Only two possible correlations were suggested. Examination of Figures 3, 4, 5, 6 and 7 shows that at many points the curve representing the titer of lysozyme in the nasal secretions tends to follow the curve representing the level of vitamin $A$ in the plasma. The parallelism is not consistent, however, and in several instances the two curves obviously diverge. In the two patients subjected to prolonged deprivation of vitamin $C$ and vitamin $A$, respectively (Figures 5 and 7), another feature was observed. In the periods at the beginning and end of the study when the vitamin levels in the blood were normal a rather constant fluctuation in the titers of lysozyme and virus inactivating substance in the nasal secretions was seen but in the interval of prolonged vitamin deprivation the fluctuations disappeared and a constant level was obtained. The data do not permit of any further comment.

In view of the reported influence of vitamin C upon complement $(15,16)$, it is interesting to note that in the cases herein reported the complement titrations were rather uniform whether the vitamin $C$ stores were depleted or whether an excess of vitamin $\mathrm{C}$ was administered. This is in accord with acute experiments described by Spink et al. (19). The results in general have failed to disclose a significant effect of vitamin A or vitamin $C$ upon the phenomena involved in the serological tests.

The immunological tests employed in this study represent reactions that have been found to occur under conditions of health. Whether or not they may serve as reliable indices of resistance to infection is not certain since their rôle in the natural resistance of man has not been clearly determined. Because of the multiplicity of factors that constitute the mechanisms of virulence, susceptibility and host resistance, it is obvious that broad conclusions cannot be drawn from the present findings. However, the tests that were employed were arbitrarily selected because of their diversity and because each represents a biological phenomenon which is either antibacterial or antiviral in its action. They illustrate, therefore, certain 
types of immunological reactivity of the patients under conditions of vitamin deficiency and adequacy and furnish information concerning them. Certain additional observations suggest that not only was the immunological reactivity of the patients, as measured by the tests, unimpaired, but that the ability of the patients to resist infection was also intact. L. N. developed a hemolytic streptococcal pharyngitis during the time when he was severely depleted of vitamin $C$, yet the clinical course of the infection was not remarkable and recovery was complete despite the lack of specific therapy. Furthermore, in this same patient the titers of influenza virus inactivating substance in the nasal secretions and influenza virus neutralizing antibody in the serum tended to increase during the time when he was being depleted of vitamin C and there was no ascorbic acid detectable in the plasma. A. M. was repeatedly exposed to L. N. when he had the pharyngitis, yet A. M. developed no signs of illness despite the fact that he was on the diet deficient in vitamin $\mathrm{A}$. It is to be recalled that J. M. developed type specific antibodies for type two pneumococci in his serum when he was severely depleted of vitamin C. This was presumably due to an infectious stimulus, yet no signs of illness appeared. Only one of the patients contracted severe colds during the period of study and he (T. O.) had two rather severe upper respiratory infections at the time when he was receiving large doses of vitamin $\mathrm{A}$ and vitamin C daily.

It was not the purpose of the study to produce the clinical manifestations of a deficiency either of vitamin A or vitamin C. Severe depletion of vitamin $C$ was produced in each of two subjects but a parallel deficiency in vitamin $\mathrm{A}$, as measured by the level of the vitamin in the plasma, was not produced by a diet low in the vitamin in spite of the fact that one patient was kept on such a diet for 17 consecutive weeks. Apparently, the production of a deficiency in vitamin A requires considerably more time than had been allowed. This is probably due to the fact that the stores of vitamin $\mathrm{A}$ in the livers of human individuals are considerable (20). Murrill et al. (21) kept two normal persons on a diet deficient in vitamin $A$ for 39 and 42 days, respectively, but the plasma levels of the vitamin were not significantly altered. They concluded that the concentration of vitamin
$A$ in the plasma is altered only in extreme cases of vitamin A deficiency.

It was interesting that the level of carotene in the plasma fell significantly in each of the patients on the diet low in vitamin A (and carotene). It is probable that the decrease in the plasma levels of carotene may be taken as evidence of the limited amount of available vitamin $\mathrm{A}$ in the diet since carotene is the precursor of vitamin $A$ and is the form in which the vitamin is normally ingested. Murrill et al. (21) also noted a decrease in the plasma levels of carotene in their two patients kept on diets low in vitamin $\mathrm{A}$.

\section{SUMMARY}

The influence of vitamin $A$ and vitamin $C$ upon a series of immunological phenomena in human individuals has been investigated. Each of five patients was given a diet adequate in all factors but for the specific vitamin, the effect of which was to be determined. The subjects were studied for periods of $14,26,20,6$ and 19 weeks, respectively. Determinations of the amount of vitamin $A$, carotene and vitamin $C$ in the plasma and, in certain instances, measurements of the concentration of vitamin $C$ in the white blood cell-platelet layer were made at weekly or bi-weekly intervals. At similar intervals, observations were made on the following immunological reactions: (1) the capacity of the patient's nasal secretions to inactivate influenza virus; (2) the titer in the patient's blood serum of neutralizing antibodies for influenza virus; (3) the activity of lysozyme in the nasal secretions; (4) the titer of complement in blood serum; and (5) the phagocytic activity for pneumococci of polymorphonuclear neutrophilic leukocytes in heparinized blood.

The results of the various immunological tests were not significantly influenced by the following conditions: (1) marked and prolonged changes in the plasma levels of vitamin $A$ or vitamin $C$ or abrupt rises in the concentration of vitamin $A$ in the plasma (two patients); (2) severe deficiency in vitamin $\mathrm{C}$ followed by a period during which the subjects were flooded with the vitamin (two patients); (3) a period of 17 consecutive weeks on a regime deficient in vitamin $A$ followed by a period of 2 weeks during which the subject received large doses of the vitamin daily. Certain 
variations in the results of the immunological tests occurred but these alterations were either no more marked than those occurring in normal persons or were adequately explained on some basis other than a deficiency or sufficiency of vitamin A or vitamin $\mathrm{C}$.

The authors wish to express their appreciation of the assistance given by Drs. Eli Bauman and Sol Sherry in the early part of the study.

\section{BIBLIOGRAPHY}

1. Perla, D., and Marmorston, J., Natural Resistance and Clinical Medicine. Little, Brown and Co., Boston, 1941.

2a. Clausen, S. W., The influence of nutrition upon resistance to infection. Phys. Rev., 1934, 14, 309.

b. Robertson, E. C., The vitamins and resistance to infection. Medicine, 1934, 13, 123.

c. Clausen, S. W., The Pharmacology and Therapeutics of Vitamin A. The Vitamins, American Medical Association, Chicago, 1939.

d. Abt, A. F., and Farmer, C. J., Vitamin C, Pharmacology and Therapeutics. The Vitamins, American Medical Association, Chicago, 1939.

3a. Francis, T.; Jr., Inactivation of epidemic influenza virus by nasal secretions of human individuals. Science, 1940, 91, 198.

b. Francis, T., Jr., The Significance of Nasal Factors in Epidemic Influenza. Problems and Trends in Virus Research. University of Pennsylvania Press, Philadelphia, 1941, p. 41.

4. Kimble, M. S., The photocolorimetric determination of vitamin $A$ and carotene in human plasma. $J$. Lab. and Clin. Med., 1939, 24, 1055.

5. Stueck, G. H., Flaum, G., and Ralli, E. P., The serum carotene in diabetic patients. J. A. M. A., 1937, 109, 343.

6. Mindlin, R. L., and Butler, A. M., The determination of ascorbic acid in plasma; a macromethod and micromethod. J. Biol. Chem., 1938, 122, 673.

7. Butler, A. M., and Cushman, M., Distribution of ascorbic acid in the blood and its nutritional significance. J. Clin. Invest., 1940, 19, 459.

8a. Ralli, E. P., Bauman, E., and Roberts, L. B., The plasma levels of vitamin $A$ and carotene in nor- mals, in diabetes mellitus and in cirrhosis of the liver. (In press.)

b. Idem, The plasma levels of vitamin A after the ingestion of standard doses: Studies in normal subjects and patients with cirrhosis of the liver. J. Clin. Invest., 1941, 20, 709.

9. Ralli, E. P., Friedman, G. J., and Sherry, S., The vitamin $C$ requirement of man. J. Clin. Invest., 1939, 18, 705.

10. Francis, T., Jr., Transmission of influenza by a filterable virus. Science, 1934, 80, 457.

11. Reed, L. J., and Muench, H., A simple method of estimating fifty per cent end points. Am. J. Hyg., 1938, 27, 493.

12a. Fleming, A., On a remarkable bacteriolytic element found in tissues and secretions. Proc. Roy. Soc., London, s.B., 1922, 93, 306.

b. Thompson, R., Lysozyme and its relation to antibacterial properties of various tissues and secretions. Arch. Path., 1940, 30, 1096.

13. Crandon, J. H., Lund, C. C., and Dill, D. B., Experimental human scurvy. New England J. Med., 1940, 223, 353.

14. Ralli, E. P., and Sherry, S., Adult scurvy and the metabolism of vitamin C. Medicine, 1941, 20, 251.

15. Ecker, E. E., Pillemer, L., Griffitts, J. J., and Schwartz, W. P., Complement and ascorbic acid in human scurvy. J. A. M. A., 1939, 112, 1449.

16. Chu, Fu-T'ang, and Chow, B. F., Correlation between vitamin $\mathrm{C}$ content and complement titer of human blood plasma. Proc. Soc. Exper. Biol. and Med., 1938, 38, 679.

17. Ralli, E. P., and Friedman, G. J., The response to the feeding of cevitamic acid in normal and deficient subjects as measured by a vitamin $\mathrm{C}$ excretory test. Ann. Int. Med., 1938, 11, 1996.

18. Ecker, E. E., Pillemer, L., Wertheimer, D., and Gradis, H., Ascorbic acid and complement function. J. Immunol., 1938, 34, 19.

19. Spink, W. W., Michelsen, O., and Agnew, S., The relation of ascorbic acid to human complement. J. Clin. Invest., 1941, 20, 434.

20. Ralli, E. P., Papper, E., Paley, K., and Bauman, E., The vitamin A content of the liver in normal and diseased subjects. Arch. Int. Med., 1941, 68, 102.

21. Murrill, W. A., Horton, P. B., Leiberman, E., and Newburgh, L. H., Vitamin A and carotene. II. Vitamin A and carotene metabolism in diabetics and normals. J. Clin. Invest., 1941, 20, 395. 